\author{
Bożena WójTowicz \\ Uniwersytet Pedagogiczny w Krakowie, Polska \\ Pedagogical University of Cracow, Poland
}

\title{
Zmiany w ruchu turystycznym Hawajów w latach 2005-2015
}

\section{Changes in the Tourist Flows in the Hawaiian Islands in the Period of 2005-2015}

Streszczenie: Ruch turystyczny odgrywa istotną rolę w rozwoju turystyki na świecie. Jednym z najlepiej zagospodarowanych i najczęściej odwiedzanych przez turystów regionów są Hawaje. Zmiany w jego układzie przestrzennym warunkowane są z jednej strony popytem wewnętrznym i zewnętrznym, z drugiej zaś możliwościami rozwoju poszczególnych wysp. Celem pracy była analiza zmian w ruchu turystycznym w układzie przestrzennym i czasowym w odniesieniu do pięciu wysp hawajskich: 0'ahu, Maui, Kaua'i, Moloka'i i Hawai'i Island. Analizy statystyczne wykonano z wykorzystaniem danych pochodzących z Report Hawai Tourism Authority 2005 do 2015, banku danych of Hawaii Offers a Safe Port. Wyniki badań wskazują na zmiany w ruchu turystycznym w latach 2005-2015. W roku 2007 odwiedziło Hawaje ponad 7,6 mln osób, w 2009 roku kryzys gospodarczy w USA i Japonii spowolnił przepływ turystów o ponad 1,1 mln, a ponowny jego wzrost odnotowano rok później i w kolejnych latach. Największy ruch turystyczny obserwuje się na wyspie O'ahu. Turyści krajowi stanowili ponad $67 \%$ odwiedzających Hawaje. Rozwój funkcji turystycznych wysp jest zróżnicowany i zależy nie tylko od wielkości ruchu turystycznego i motywów przyjazdu, ale również od zagospodarowania turystycznego. Cechą charakterystyczną współczesnej turystyki na Hawajach jest jej masowość, ekspansja przestrzenna oraz wzrost standardu usług.

Abstract: Tourist traffic plays an important role in the development of tourism in the world. The Hawaiian Islands are one of the best developed regions, as well as regions that are most frequently visited by tourists. Changes in the spatial arrangement (layout) are determined by, on the one hand, internal and external demands, and, on the other hand, development possibilities of individual islands. The aim of this article is to establish the changes in the range of tourist flows (tourist attendance) in spatial and temporal arrangement (layout) in the field of five islands within the range of the Hawaiian Islands, namely O'ahu, Maui, Kaua'i, Moloka'i and Hawai'i. The statistical analysis was performed on the basis of the data from the Report prepared by the Hawaii Tourism Authority 2005-2016 and the data from the Bank of Hawaii. Results of the research indicate changes in tourist flows (attendance) in the years 2005-2015. According to the data, the Hawaii Islands were visited by over 7.6 million people in 2007. In 2009 the economic crisis in the US and Japan slowed the flow of tourists by over 1.1 million, and its subsequent increase was recorded a year later, as well as in the following years. The greatest tourist flows were observed on the island of O'ahu. Domestic tourists constitute over $67 \%$ of the visitors to Hawaii. The development of touristic functions of the islands is diverse and depends not only on the size of the tourist flows as well as arrival reasons, but also on the touristic management. Moreover, the characteristic features of the existing tourism in Hawaii focus on the mass scale, spatial expansion and the increase in the standard of services. 
Słowa kluczowe: atrakcje i walory turystyczne; funkcje turystyczne; Hawaje; ruch turystyczny; zagospodarowanie turystyczne

Keywords: development of tourism; the Hawaiian Islands; tourist attractions and tourist values; tourist flows (tourist attendance); tourist functions

Otrzymano: 30 grudnia 2017

Received: 30 December 2017

Zaakceptowano: 17 maja 2018

Accepted: 17 May 2018

Sugerowana cytacja/ Suggested citacion:

Wójtowicz, B. (2018). Zmiany w ruchu turystycznym Hawajów w latach 2005-2015. Prace Komisji Geografii Przemysłu Polskiego Towarzystwa Geograficznego, 32(2), 325-337. https://doi.org/10.24917/20801653. 322.23

\section{WSTĘP}

Ruch turystyczny jest zjawiskiem społeczno-ekonomicznym o złożonym charakterze, odgrywającym znaczącą rolę w gospodarce światowej. Hawaje to jeden z najpiękniejszych archipelagów na Oceanie Spokojnym, wymarzony kierunek podróży milionów turystów z całego świata. Niespotykane w innych regionach świata krajobrazy, różnokolorowe plaże, niesamowita kultura oraz atmosfera wysp przyciągają turystów przez cały rok.

Ruch turystyczny to określenie przemieszczania się ludzi, które nie jest wymuszone przez czynniki zewnętrzne - ludzie zmieniają miejsce pobytu, swoje środowisko, rytm życia dobrowolnie - bez przymusu. Ruch turystyczny odnosi się do określonego obszaru, kierunku, okresu, w którym trwa (Kowalczyk, 2000). Pojęcie ruchu turystycznego w literaturze polskiej zostało szczegółowo omówione.

W literaturze przedmiotu istnieje wiele podziałów ruchu turystycznego (Jackowski, Warszyńska, 1979). Na początku XX wieku w literaturze naukowej zwrócono uwagę na znaczenie, potrzeby oraz motywacje w ruchu turystycznym (Pearce, Stringer, 1991; Merkel-Masse, Wichrowska, 2010). Celem niniejszego artykułu jest przedstawienie wielkości ruchu turystycznego, destynacji turystycznych, motywów przyjazdu, zagospodarowania turystycznego, konkurencyjności oraz funkcji turystycznej głównych wysp hawajskich.

\section{PROBLEMATYKA I CEL BADAWCZY}

Podjęcie tematyki ruchu turystycznego na Hawajach wynika z faktu, że jest to najatrakcyjniejszy i najczęściej odwiedzany region archipelagu wysp na świecie, który coraz bardziej oddziałuje na generowanie różnorodnych, pozytywnych następstw gospodarczych i społecznych. Uprawianie turystyki stało się dostępne dla każdego. Podróże turystyczne stanowią wciąż dominującą ilościowo formę turystyki, która związana jest z czasem wolnym (urlopami, wycieczkami). Celem pracy było przedstawienie dynamiki ruchu turystycznego poszczególnych wysp archipelagu Hawajów w latach 2005-2015 i jego uwarunkowań wynikających z atrakcyjności położenia geograficznego i warunków przyrodniczych. W części empirycznej przeprowadzono analizę ruchu turystycznego na Hawajach w latach 2005-2015 z podziałem na turystów krajowych 
i zagranicznych, zbadano również gęstość ruchu turystycznego i jego natężenie, ruch turystyczny na głównych wyspach hawajskich w latach 2005-2015 i ich zagospodarowanie. Przeanalizowano pochodzenie turystów odwiedzających Hawaje w 2015 roku, średnią długość pobytu według pochodzenia turystów z uwzględnieniem poszczególnych wysp oraz główne cele podróży. W celu przedstawienia rozwoju funkcji turystycznych na Hawajach oraz zagospodarowania turystycznego zastosowano metody statystyczne, wykorzystując dwa wskaźniki: Deferta i Schneidera.

\section{ATRAKCJE TURYSTYCZNE}

Archipelag hawajski tworzy 137 wysp, mniejszych wysepek i atoli, które rozciągają się na półkuli północnej na przestrzeni $2450 \mathrm{~km}$. Tylko osiem wysp archipelagu ma znaczenie turystyczne i zajmuje blisko 99\% jego powierzchni (Długosz, 2014: 149). Hawaje położone są w centrum Pacyficznego Pierścienia Ognia (Swenson, 2008). Archipelag jest obszarem górzystym i aktywnym sejsmicznie. Na jego powierzchni zlokalizowanych jest wiele czynnych i wygasłych wulkanów (Makowski, 2008). Średnia wysokość wysp wynosi 925 m n.p.m. Największymi szczytami są wulkany Mauna Kea (4205 m n.p.m.) raz Mauna Loa (4170 m n.p.m.). Największą wyspą Hawajów jest Big Island (Hawai'i Island) (10 $\left.432 \mathrm{~km}^{2}\right)$. Pozostałe większe wyspy to: Maui, O'ahu, Kaua'i, Moloka'i. Oddalone są od najbliższego kontynentu Ameryki Północnej o ponad 4 tys. km.

O sławie tego zakątka Ziemi wśród turystów zdecydował sprzyjający klimat i unikalny krajobraz wulkaniczny. Izolacja wysp oraz zróżnicowanie środowiska (duże wysokości i tropikalny klimat) stworzyły różnorodność endemicznej flory i fauny (Linda, Cuddihy, Stone, 1990). Jedną z największych atrakcji turystycznych Hawajów jest Park Narodowy Wulkany Hawai'i, który został założony w 1916 roku. Można w nim podziwiać niesamowity krajobraz wulkaniczny. Na jego terenie znajdują się dwa najbardziej aktywne oraz największe wulkany na świecie, co pozwala naukowcom prowadzić liczne badania dotyczące procesów geologicznych, które doprowadziły do powstania archipelagu wysp hawajskich, jak i kontynuować badania nad procesami zachodzącymi we wnętrzach wulkanów (Chegaray, 1960). W Parku turyści mogą podziwiać bardzo rzadkie gatunki zwierząt i roślin. Na wyspie Maui znajduje się Park Narodowy Haleakala, będący początkowo częścią Parku Narodowego Wulkany Hawai'i. Rozciąga się na powierzchni $118 \mathrm{~km}^{2}$. Jego nazwa w języku hawajskim oznacza "dom słońca” Jedną z głównych atrakcji turystycznych parku jest okolica krateru wulkanu Haleakalā (Skoczek, 2005).

Honolulu to największe miasto archipelagu wysp hawajskich i jednocześnie stolica stanu. Jest głównym ośrodkiem międzynarodowego biznesu oraz obrony militarnej, ponieważ na jego terenie znajduje się Pearl Harbor. Molokini to malutka wyspa znajdująca się $4 \mathrm{~km}$ od wybrzeża wyspy Mauri. Powstała w wyniku zalania krateru wulkanu, jest obecnie wyjątkową atrakcją turystyczną, ponieważ jej kształt przypomina półksiężyc. Przyciąga również wielbicieli nurkowania - woda wokół niej jest niezwykle czysta i przejrzysta, a widoczność sięga 46 m (Skoczek, 2005). Atrakcję turystyczną na wyspie Kauai stanowi jeden z najwyższych wodospadów na Hawajach, liczący 35 m wysokości. Zatoka Hanuma, czyli „krzywa zatoka”, to bardzo popularna i oblegana przez turystów atrakcja turystyczna, będąca też parkiem narodowym z przepiękną rafą koralową. Hanauma jest również miejscem występowania zielonych morskich żółwi (Ariyoshi, 2010). 
Centrum Kultury Polinezyjskiej to park tematyczny lub - jak niektórzy je nazywają - „żywe muzeum”. Znajduje się na północnym wybrzeżu wyspy 0’ahu. Oprócz tradycyjnych i stałych wystaw turyści mogą wziąć udział w prezentacji kultury hawajskiej, gdzie artyści przedstawiają wielokulturowy charakter Polinezji, np. poprzez prezentowanie tradycyjnych tańców.

\section{DYNAMIKA RUCHU TURYSTYCZNEGO}

W 1954 roku na Hawaje przyjechało ponad 91166 turystów, natomiast w 2015 roku liczba ta osiągnęła ponad 8,5 mln osób. Ruch turystyczny zaczął się rozwijać od ustanowienia stanu Hawaje w 1959 roku. Turystyka stała się główną gałęzią gospodarki wysp, a Hawaje stały się jednym z najważniejszych regionów turystycznych świata. Od lat pięćdziesiątych XX wieku liczba turystów odwiedzających Hawaje wzrosła ponad ośmiokrotnie (Annual Visitor Research Report Hawai'i Tourism Authority, 2003). Ze względu na łagodną pogodę przez cały rok, podróże turystyczne są popularne niezależnie od pory roku, a dochód z turystyki w 1997 roku wynosił 24,3\% produktu stanowego brutto. Większość ruchu turystycznego koncentruje się na O’ahu, ale i inne hawajskie wyspy przyciągają turystów swoimi walorami. W 2003 roku, według danych rządowych, na wyspy hawajskie przybyło ponad 6,4 mln osób, których wydatki wyniosły ponad 10,6 mld dol.

W literaturze naukowej zajmowano się ruchem turystycznym, czynnikami rozwoju turystyki, motywami i zagospodarowaniem wysp hawajskich (Huetz de Lemps, 1989; Gay, 1999; Crocombe, 2001; Compendium of Tourism Statistics, 2003; Woo, 2009; Kubota, 2010; Yonan, 2010; Wiles, 2012; Gill, 2016).

Większą część turystów na wyspach stanowią turyści krajowi, pochodzący ze Stanów Zjednoczonych. Analizując dynamikę rozwoju ruchu turystycznego na Hawajach w latach 2005-2015, możemy zauważyć, że liczba turystów ma tendencję wzrostową. W 2005 roku Hawaje odwiedziło blisko 7,5 mln osób, a w 2015 roku - ponad 8,5 mln. Nie jest to bardzo imponujący wzrost, jednakże należy zwrócić uwagę na fakt, iż w latach 2008-2009 nastąpił spadek liczby turystów odwiedzających Hawaje do ok. 6,5 mln, co było zapewne związane z kryzysem ekonomicznym, który miał duży wpływ na wielkość ruchu turystycznego nie tylko na Hawajach ale na całym świecie. Ze względu jednak na swoistą izolację Hawajów, kryzys nie był tam tak bardzo dotkliwy. Od 2010 roku obserwujemy ponownie stopniowy wzrost liczby turystów (ryc. 1).

Analizując ruch turystyczny na Hawajach, możemy zobaczyć wyraźną dominację wyspy 0’ahu. Spośród pięciu analizowanych wysp 0’ahu odwiedziło ponad 50\% przybyłych turystów. Wyspa notuje tak duży ruch turystyczny, ponieważ znajduje się tu stolica stanu Honolulu z największym na wyspach międzynarodowym lotniskiem. Średnio każdego dnia lotnisko w Honolulu odnotowuje ponad 22 tys. przybyłych turystów, w miesiącach letnich liczba ta wzrasta do przeszło 35 tys. 0’ahu nie jest największą wyspą, ale posiada najwięcej atrakcji turystycznych, zarówno przyrodniczych (stożki wulkaniczne - Diamond Head, Park Stanowy Koko Head, ogród botaniczny z kolekcją kaktusów, baobabów, palm, aloesu, wężownic, wilczomleczy itd., rezerwat przyrody Hanauma Bay), jak i kulturowych. Na wyspie znajduje się rozrywkowe i kulturalne centrum Hawajów (Ariyoshi, 2010). Turyści przybywający na O'ahu to przede wszystkim osoby chcące wypocząć, a wieczorami się zabawić. 
Ryc. 1. Ruch turystyczny na Hawajach w latach 2005-2015

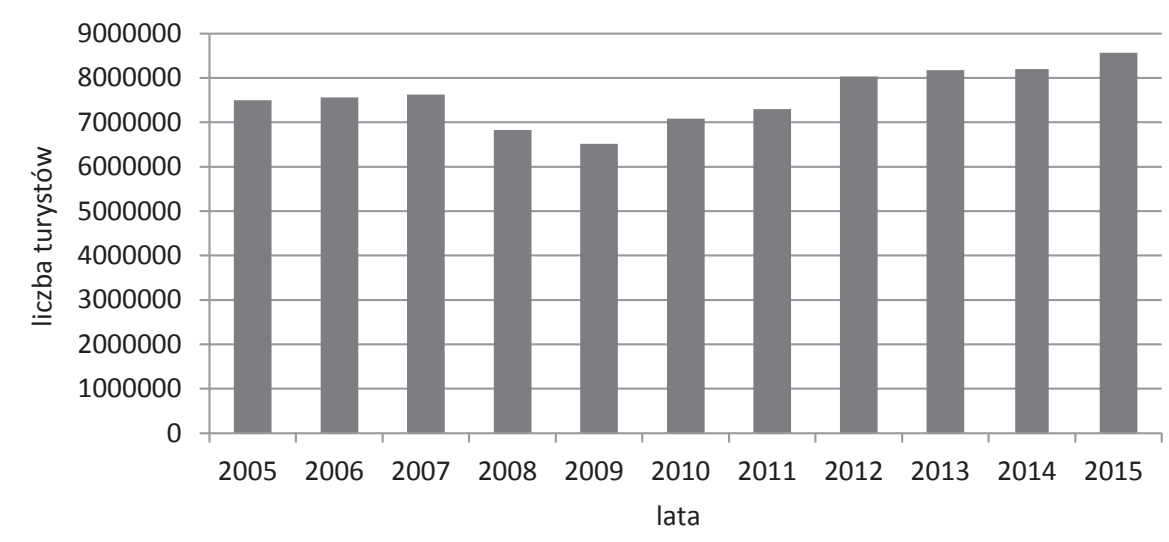

Źródło: opracowanie własne na podstawie roczników statystycznych Annual Visitor Research Report Hawai'i Tourism Authority (2005-2015)

Drugą najczęściej odwiedzaną wyspą jest Maui, którą odwiedziło w 2015 roku blisko 24\% turystów. Jest to druga po względem powierzchni wyspa Hawajów. 0 ruchu turystycznym na Maui decydują w głównej mierze atrakcje przyrodnicze. Należą do nich uśpiony wulkan Haleakala - „Dom Słońca”, wodospady: Makahiku i Waimoku o wysokości ok. $61 \mathrm{~m}$. Wyspa jest także znana ze swoich kilkudziesięciu malowniczych plaż kąpielowych z piaskiem o kolorze od czarnego, przez granatowy, aż do żółtego i białego (Cook, Word, Perry, 2005: 832-868).

Trzecią najczęściej odwiedzaną wyspą jest Big Island. Jej turystyka opiera się wyłącznie na Parku Narodowym Czynnych Wulkanów, które są symbolem Hawajów. Został on wpisany w 1987 roku na listę światowego dziedzictwa UNESCO. W parku można zaobserwować bogactwo różnorodnych formacji roślinnych, począwszy od tropikalnego lasu deszczowego 'Ola’a do zarośli i łąk z Ka’u lub alpejskiej tundry Mauna Loa (Ariyoshi, 2010).

Najrzadziej odwiedzaną z wysp jest Moloka'i, położona w samym centrum, najmniejsza z większych wysp archipelagu, zwana „przyjazną wyspą” ze względu na zamieszkujących ją rdzennych Hawajczyków, którzy żyją zgodnie z duchem aloha. Odwiedza ją zaledwie 0,6\% turystów. Ze względu na małą popularność wyspy Moloka'i jest to idealne miejsce dla tych turystów, którzy chcą spędzić czas spokojnie, na wyciszeniu się i rozmyślaniu. Wyspa pozostaje niezmieniona od czasów Królestwa Hawajskiego, a jej gospodarka opiera się bardziej na plantacjach trzciny cukrowej i ananasów niż na turystyce. Półwysep Kalaupapa to sztandarowe miejsce na wyspie, znajduje się tu Kalaupapa National Historical Park. Jest to otoczone pięknymi krajobrazami „więzienie”, do którego zsyłano trędowatych z całych Hawajów.

Różnica pomiędzy liczbą turystów na poszczególnych wyspach a ogólną liczbą turystów na Hawajach wynika z tego, iż turysta przybywający na Hawaje często podróżuje pomiędzy wyspami i nie spędza całego swojego pobytu tylko na jednej z nich.

Porównując Hawaje pod względem gęstości ruchu turystycznego, można również zauważyć, że największą ma wyspa O’ahu. Jeśli średnia gęstość natężenia ruchu 
turystycznego wynosi 590,6 osób na $\mathrm{km}^{2}$ na Hawajach (tab. 1), to na O’ahu liczba ta przekracza 3455 osób na $\mathrm{km}^{2}$, co stanowi blisko sześć razy większą gęstość w stosunku do całego zamieszkałego archipelagu. Wskaźnik jest tak duży, ponieważ znajduje się tu stolica Hawajów - Honolulu.

Najmniejsza gęstość ruchu turystycznego notowana jest na wyspie Moloka'i (96 osób na $\mathrm{km}^{2}$ ) ze względu na małą liczbę odwiedzających ją turystów oraz na Big Island (145 os na $\mathrm{km}^{2}$ ), pomimo tego że odwiedza ją dużo turystów (tab. 1).

Zupełnie inaczej wygląda sytuacja w natężeniu ruchu turystycznego. Pierwsza pod względem gęstości ruchu turystycznego w 2015 roku 0'ahu jest na ostatnim miejscu pod względem wskaźnika natężenia ruchu, który wynosi 561. Średnie natężenie ruchu na Hawajach wynosi 784, co oznacza, że O'ahu znajduje się poniżej przeciętnej, a uwarunkowane jest to bardzo dużą populacją wyspy, którą zamieszkuje ponad 954 tys. osób. Bardzo duże natężenie ruchu turystycznego obserwuje się natomiast na wyspach Kaua'i i Maui. Kolejno Kaua'i notuje wskaźnik na poziomie 1787, a Maui 1759. Wskaźniki na tych wyspach blisko trzykrotnie przewyższają średni wskaźnik dla Hawajów. Uwarunkowane jest to liczbą ludności zamieszkującej te wyspy. Na Maui liczba ludności wynosiła ponad 144 tys. osób, a na Kaua’i ok. 66 tys. (tab. 1).

Tab. 1. Wielkość ruchu turystycznego, gęstość oraz natężenie ruchu turystycznego na poszczególnych wyspach hawajskich w 2015 roku

\begin{tabular}{|c|c|c|c|c|}
\hline \multicolumn{4}{|c|}{ Wielkość ruchu turystycznego na Hawajach w 2015 roku } & \multirow{2}{*}{$\begin{array}{c}10633566 \\
\text { Udział } \\
\text { procentowy (\%) }\end{array}$} \\
\hline Wyspa & $\begin{array}{l}\text { Liczba } \\
\text { turystów }\end{array}$ & $\begin{array}{c}\text { Gęstość ruchu } \\
\text { turystycznego (na km²) }\end{array}$ & $\begin{array}{c}\text { Natężenie ruchu } \\
\text { turystycznego (na } 100 \text { osób) }\end{array}$ & \\
\hline O’ahu & 5339912 & 3455,6 & 561 & 50,22 \\
\hline Maui & 2540162 & 1348,7 & 1759 & 23,89 \\
\hline Big Island & 1514973 & 145,2 & 812 & 14,25 \\
\hline Moloka'i & 64767 & 96,1 & 852 & 0,60 \\
\hline Kaua'i & 1173752 & 820,5 & 1787 & 11,04 \\
\hline Razem & 10633566 & 590,6 & 784 & 100,00 \\
\hline
\end{tabular}

Źródło: opracowanie własne na podstawie Annual Visitor Research Report Hawai’i Tourism Authority (2015)

\section{CZYNNIKI GENERUJĄCE PRZESTRZENNE ZRÓŻNICOWANIE RUCHU TURYSTYCZNEGO}

Największy ruch turystyczny obserwuje się na wyspie 0’ahu. Porównując dane w tab. 2, można zauważyć, że zanotowano największy wzrost liczby turystów od 2005 roku i jest to wzrost o ponad $11 \%$. W 2005 roku wyspę odwiedziło ponad 4,7 mln turystów, a w 2015 roku - ponad 5 mln osób. Widać niewielki spadek liczby turystów w latach 2008 i 2009, ale już w 2010 roku, wraz z opanowaniem światowego kryzysu ekonomicznego, liczba ta zaczęła wzrastać i utrzymuje tendencję wzrostową po dzień dzisiejszy.

Największy spadek liczby turystów obserwuje się na wyspie Moloka'i - ok. 14\%. Może to być spowodowane pewnego rodzaju odizolowaniem się wyspy od turystycznego archipelagu. Moloka'i wcześniej przyciągała swoją surowością i dzikością, ale obecnie turysta wymaga czegoś więcej, zapewnienia rozrywki, idealnych warunków noclegowych, wielu różnorodnych atrakcji, których wyspa nie jest w stanie mu zapewnić. Od 2005 roku, kiedy to wyspę odwiedziło ponad 73 tys. osób, liczba ta regularnie spada, jednakże utrzymuje się w ostatnich dwóch latach na poziomie powyżej 60 tys. 
odwiedzających. W 2015 roku odwiedziło wyspę blisko 65 tys. turystów. Rekordowy ruch turystyczny miał miejsce w 2006 roku, kiedy wyspę odwiedziło najwięcej, ponad 95 tys. osób. Być może dlatego, że w tych latach pojawiła się moda na ekoturystykę.

Spadek liczby turystów zanotowała także Hawai'i Island (ok. 5\%). Jest on niewielki w porównaniu do Moloka'i i spowodowany powolną odbudową liczby turystów po kryzysie w 2008 roku. Pozostałe wyspy: Maui i Kaua'i odnotowały większy wzrost, ponad 7\% i 9\%, w 2015 roku w stosunku do 2005 roku (tab. 2a). Można zaobserwować wyraźną dominację wyspy 0’ahu oraz spadek liczby turystów w 2008 i 2009 roku.

Tab. 2. Ruch turystyczny na głównych wyspach hawajskich w latach 2005-2009

\begin{tabular}{|l|r|r|r|r|r|}
\hline & \multicolumn{1}{|c|}{2005} & \multicolumn{1}{|c|}{2006} & \multicolumn{1}{c|}{2007} & \multicolumn{1}{c|}{2008} & \multicolumn{1}{c|}{2009} \\
\hline O'ahu & 4731842 & 4727496 & 4823874 & 4303094 & 4119517 \\
\hline Maui & 2294697 & 2516215 & 2580361 & 2171610 & 1976852 \\
\hline Moloka'i & 73506 & 95510 & 86579 & 73187 & 52907 \\
\hline Kaua'i & 1090147 & 1270013 & 1372682 & 1101753 & 998918 \\
\hline Hawai'i Island & 1521536 & 1687986 & 1739458 & 1420487 & 1299711 \\
\hline
\end{tabular}

Źródło: opracowanie własne na podstawie Annual Visitor Research Report Hawai’i Tourism Authority (2005-2009)

Tab. 2a. Ruch turystyczny na głównych wyspach hawajskich w latach 2010-2015

\begin{tabular}{|l|r|r|r|r|r|r|r|}
\hline & 2010 & 2011 & 2012 & 2013 & 2014 & 2015 & $\begin{array}{c}\text { Zmiana } \\
2005-2015 \\
(\%)\end{array}$ \\
\hline O’ahu & 4427372 & 4525696 & 4904045 & 5044275 & 5192621 & 5339912 & 11,4 \\
\hline Maui & 2186279 & 2283728 & 2309194 & 2358783 & 2417417 & 2540162 & 9,7 \\
\hline Moloka'i & 52257 & 57556 & 53323 & 55157 & 60100 & 64767 & $-14,0$ \\
\hline Kaua'i & 1042632 & 1115628 & 1084681 & 1114354 & 1119973 & 1173752 & 7,2 \\
\hline Hawai'i Island & 1378921 & 1433588 & 1433282 & 1435245 & 1454684 & 1514973 & $-5,0$ \\
\hline
\end{tabular}

Źródło: opracowanie własne na podstawie Annual Visitor Research Report Hawai’i Tourism Authority (2010-2015)

W celu przedstawienia rozwoju funkcji turystycznych na Hawajach oraz zagospodarowania turystycznego zastosowano metody statystyczne, wykorzystując dwa wskaźniki: Deferta i Schneidera.

Tab. 3. Wskaźniki rozwoju funkcji turystycznej (wskaźnik Deferta) i gęstości ruchu turystycznego (wskaźnik Schneidera) na wyspach hawajskich w 2015 roku

\begin{tabular}{|l|c|c|c|}
\hline \multicolumn{1}{|c|}{ Nazwa wyspy } & $\begin{array}{c}\text { Liczba miejsc } \\
\text { noclegowych }\end{array}$ & $\begin{array}{c}\text { Wskaźnik gęstości } \\
\text { bazy noclegowej } \\
\text { Deferta }\end{array}$ & $\begin{array}{c}\text { Wskaźnik natężenia } \\
\text { ruchu turystycznego } \\
\text { (na 100 osób) } \\
\text { Schneidera }\end{array}$ \\
\hline O'ahu & 36058 & 3,8 & 23,34 \\
\hline Maui & 20972 & 14,5 & 11,14 \\
\hline Big Island & 11085 & 5,9 & 1,07 \\
\hline Moloka'i & 189 & 2,56 & 0,28 \\
\hline Kaua'i & 8582 & 13,07 & 6,01 \\
\hline
\end{tabular}

Źródło: opracowanie własne na podstawie Visitor Plant Inventory Report. Hawai’i Tourism Authority Tourism Research (2016) 
Wyspą wyróżniającą się największym wskaźnikiem rozwoju funkcji turystycznej w 2015 roku jest Maui (14,5) (tab. 3). To druga co do wielkości wyspa archipelagu, na której oferowanych jest ponad 20 tys. miejsc noclegowych. Zamieszkuje ją jednak niewielu, bo ponad 144 tys. mieszkańców, dlatego wskaźnik rozwoju turystycznego jest największy. Podobnie wysoki wskaźnik rozwoju funkcji turystycznej notuje wyspa Kaua'i. Wskaźniki na tak wysokim poziomie sugerują, iż funkcja turystyczna na tych dwóch wyspach jest również na wysokim poziomie, jednakże nie jest to do końca prawdą, ponieważ dużą rolę odgrywa tu liczba ludności zamieszkująca wyspę, która ma znaczny wpływ na wielkość wskaźnika.

Najmniejszy wskaźnik rozwoju funkcji turystycznej notuje się na wyspie O’ahu $(3,8)$, która przyjmuje największą liczbę turystów i oferuje ponad 36 tys. miejsc noclegowych, ale zamieszkuje ją ponad 953 tys. mieszkańców, co ma znaczący wpływ na wysokość wskaźnika, który sugeruje, że O’ahu nie wykorzystuje swojego potencjału turystycznego.

Według wskaźnika rozwoju funkcji turystycznej można wyróżnić trzy rodzaje wysp: Maui i Kaua'i, na których funkcja turystyczna jest na wysokim poziomie, Big Island i Moloka'i, na których funkcja turystyczna jest dosyć rozwinięta, oraz O’ahu, na której potencjał turystyczny nie jest w pełni wykorzystywany.

Biorąc pod uwagę gęstość bazy noclegowej w 2015 roku, największy wskaźnik miała wyspa 0’ahu (ponad 23). Na tak wysoki wskaźnik ma wpływ niewielka powierzchnia oraz obecność Honolulu, które jest stolicą stanu i największym miastem z rozwiniętymi funkcjami turystycznymi i administracyjnymi, co powoduje rozwój bazy noclegowej. Druga co do stopnia rozwoju bazy noclegowej jest wyspa Maui. Jest to druga, zaraz po O’ahu, najpopularniejsza wyspa wśród turystów. Oferuje blisko 21 tys. miejsc noclegowych. Najmniejszy wskaźnik gęstości bazy noclegowej jest notowany na wyspie Moloka'i. Wcześniej wspomniano, że Moloka'i jest najmniej zmieniona przez człowieka ze wszystkich hawajskich wysp. Większy nacisk kładzie się tam na rolnictwo niż turystykę, dlatego baza noclegowa jest słabo rozwinięta i wyspa oferuje jedynie 189 miejsc noclegowych.

\section{DESTYNACJE RUCHU TURYSTYCZNEGO I MOTYWY PODRÓŻY}

Analizując dynamikę rozwoju ruchu turystycznego, można zauważyć, że turyści krajowi stanowią większość odwiedzających Hawaje. Od 2005 do 2007 roku ich liczba wzrosła o blisko 113 tys. osób (co stanowiło 3\%). W 2008 roku spadła ogólna liczba turystów, w tym również turystów krajowych - o 1,5\%. W następnych latach liczba wszystkich turystów wzrastała podobnie jak liczba turystów zagranicznych (tab. 4). W 2015 roku turyści krajowi stanowili ponad 67\% ogólnej liczby turystów.

W ostatnich latach wzrosła również liczba turystów zagranicznych odwiedzających Hawaje. Od 2005 do 2015 roku liczba turystów krajowych wzrosła zaledwie o ponad 391 tys. osób, natomiast liczba gości zagranicznych aż o blisko 678 tys., jest to prawie dwukrotnie większy wzrost w stosunku do ruchu krajowego. Jest to spowodowane lepszą dostępnością komunikacyjną, wzbogaceniem się społeczeństwa, ciekawością świata. Obecnie turysta oczekuje czegoś nowego, bardziej egzotycznego, niedostępnego. 
Tab. 4. Ruch turystyczny na Hawajach z podziałem na turystów krajowych i zagranicznych w latach 20052015

\begin{tabular}{|c|c|c|c|c|}
\hline Rok & Liczba turystów & Turyści krajowi & Turyści zagraniczni & $\begin{array}{c}\text { Procentowy udział } \\
\text { turystów krajowych (\%) }\end{array}$ \\
\hline 2005 & 7494236 & 5390944 & 2103292 & 71,9 \\
\hline 2006 & 7561311 & 5583330 & 1977981 & 73,8 \\
\hline 2007 & 7627819 & 5713529 & 1914290 & 74,9 \\
\hline 2008 & 6822911 & 5011368 & 1811543 & 73,4 \\
\hline 2009 & 6517053 & 4768606 & 1748447 & 73,2 \\
\hline 2010 & 7086663 & 5127122 & 1959541 & 72,3 \\
\hline 2011 & 7299047 & 5251941 & 2047106 & 72,0 \\
\hline 2012 & 8028743 & 5564626 & 2464117 & 69,3 \\
\hline 2013 & 8174461 & 5576287 & 2598174 & 68,2 \\
\hline 2014 & 8196342 & 5486059 & 2710283 & 66,9 \\
\hline 2015 & 8563018 & 5782140 & 2780878 & 67,5 \\
\hline
\end{tabular}

Źródło: opracowanie własne na podstawie Annual Visitor Research Report Hawai’i Tourism Authority (2005-2015)

Najwięcej turystów odwiedzających Hawaje stanowią turyści krajowi. Ponad 65\% z nich to mieszkańcy zachodniego wybrzeża USA. Stanowili oni 41\% wszystkich odwiedzających Hawaje w 2015 roku (ponad 3,5 mln). Jest to uwarunkowane odległością od Hawajów. Pomimo że wynosi ona ponad 4 tys. km, to i tak jest to najbliższy ląd - każdy inny zakątek świata leży jeszcze dalej od Hawajów. Ponad 34\% krajowych turystów to mieszkańcy wschodniego wybrzeża USA, których przybyło w 2015 roku ponad 1,8 mln (tab. 5).

Największą liczbę turystów zagranicznych stanowią Japończycy. W 2015 roku przyjechało ich około 1,5 mln (17\% wszystkich turystów). Blisko 6\% turystów odwiedzających wyspy to Kanadyjczycy (ponad 512 tys. osób). Trzecią destynacją archipelagu hawajskiego są mieszkańcy Oceanii, głównie: Australii i Nowej Zelandii oraz turyści z Azji (ponad 4,6\%), głównie obywatele Korei, Chin i Tajwanu. Turystów z Europy w 2015 roku przybyło zaledwie 145 tys., zapewne ze względu na największą odległość dzielącą Europę od wysp i związane z tym ogromne koszty podróży. Są to głównie obywatele bogatszych krajów: Brytyjczycy, Niemcy, Francuzi, Włosi i Szwajcarzy (Summary of 2015 Visitors to Hawai'i).

Tab. 5. Pochodzenie turystów odwiedzających Hawaje w 2015 roku

\begin{tabular}{|l|c|}
\hline \multicolumn{1}{|c|}{ Kontynent/kraj } & Udział w \% \\
\hline Wszyscy odwiedzający: 8 563 018 & 100,00 \\
\hline USA zachodnie & 40,90 \\
\hline USA wschodnie & 21,07 \\
\hline Japonia & 17,31 \\
\hline Kanada & 5,99 \\
\hline Europa & 1,70 \\
\hline Oceania & 4,67 \\
\hline Inne kraje Azji & 4,60 \\
\hline Ameryka Łacińska & 0,33 \\
\hline Pozostałe kraje & 3,40 \\
\hline
\end{tabular}

Źródło: opracowanie własne na podstawie Annual Visitor Research Report Hawai'i Tourism Authority (2015) 
Średni czas pobytu na Hawajach w 2015 roku wynosił dziewięć dni. Rozpatrując średni czas pobytu według pochodzenia turystów, można zauważyć, iż najdłużej przebywają na wyspach turyści z Europy (13 dni). Ze względu na odległość dzielącą Europę od wysp hawajskich wycieczki krótsze niż dwa tygodnie są mało opłacalne, gdyż na samą podróż tracimy co najmniej trzy lub cztery dni. Z tab. 5 możemy wyczytać pewnego rodzaju zależność, że im dalej turysta mieszka, tym dłuższy jest jego pobyt na wyspach.

Europejczycy spędzają na Hawajach najdłuższe urlopy. Zaraz po nich są Kanadyjczycy (ponad 12 dni) i mieszkańcy Ameryki Łacińskiej (11 dni). Azjaci (blisko siedem dni) i Japończycy (sześć dni) odznaczają się najkrótszym czasem pobytu, ale są oni uprzywilejowani, gdyż w momencie podróży na Hawaje zyskują jeden dzień. Turyści krajowi spędzają tam średnio ok. 10 dni (zachodni region USA - 9,28 dnia, wschodnie USA - 10,3 dnia).

Biorąc pod uwagę średnią długość pobytu na wyspach, można zauważyć, że turyści nie spędzają swojego pobytu wyłącznie na jednej z nich. Najdłuższe pobyty notuje się na wyspie Maui (osiem dni). To druga co do wielkości wyspa, na której znajduje się najwięcej atrakcji turystycznych, a na ich zobaczenie potrzeba najwięcej czasu (tab. 6). Na wyspach Kaua'i i Big Island turyści średnio spędzają ok. siedmiu dni. Przewodząca do tej pory O'ahu, jest na przedostatnim miejscu, tam turyści spędzają średnio ok. sześciu dni. O'ahu bywa często wyspą wypadową do innych, ponieważ na niej znajduje się połączenie z każdą inną wyspą, a będąc na Hawajach nie można pozostać wyłącznie na jednej wyspie, nie zobaczywszy pozostałych. Najkrótszy pobyt jest notowany na Moloka'i, najmniej turystycznej wyspie ze wszystkich, przyjeżdżają na nią i spędzają tam czas wyłącznie turyści o specyficznych wymaganiach, którzy chcą odpocząć w ciszy i spokoju od pełnych głośnych i rozrywkowych plaż wysp O’ahu i Maui.

Tab. 6. Średnia długość pobytu według pochodzenia turystów z uwzględnieniem poszczególnych wysp w 2015 roku

\begin{tabular}{|c|c|c|c|}
\hline Pochodzenie turystów & $\begin{array}{c}\text { Średnia długość pobytu na } \\
\text { Hawajach (w dniach) } \\
9,06\end{array}$ & Wyspa & $\begin{array}{l}\text { Średnia długość pobytu } \\
\text { (w dniach) }\end{array}$ \\
\hline USA zachodnie & 9,28 & O'ahu & 6,82 \\
\hline USA wschodnie & 10,30 & Maui & 8,19 \\
\hline Japonia & 5,86 & Moloka'i & 4,42 \\
\hline Kanada & 12,73 & Kaua'i & 7,63 \\
\hline Europa & 13,08 & Hawai'i Island & 7,57 \\
\hline Oceania & 9,53 & & \\
\hline Pozostałe kraje Azji & 6,75 & & \\
\hline Ameryka Łacińska & 11,53 & & \\
\hline Inne & 10,50 & & \\
\hline
\end{tabular}

Źródło: Annual Visitor Research Report Hawai'i Tourism Authority (2015)

Głównym motywem przyjazdu na Hawaje w opinii ponad 70\% turystów jest wypoczynek (hawajskie wakacje) - taki cel podróży deklarują (tab. 7). Na drugim i trzecim miejscu turyści wskazali wizytę u rodziny (ponad 8\%) oraz podróż poślubną (ok. 7\%). Inne podawane cele podróży to spotkania biznesowe i konwenty, a także chęć zawarcia związku małżeńskiego (1,4\%). Zadziwiający jest fakt, że wśród motywów turystycznych 
pojawił się taki cel, jak impuls. Ponad 1,6\% turystów stwierdziło, że wybrało się na Hawaje pod wpływem impulsu - można zauważyć, że co dla niektórych turystów jest nieosiągalnym marzeniem, dla innych okazuje się być impulsem.

Tab. 7. Główne cele podróży na Hawaje

\begin{tabular}{|l|c|}
\hline \multicolumn{1}{|c|}{ Cele podróży } & Udział w \% \\
\hline Wypoczynek podczas wakacji & 74,1 \\
\hline Wizyta u rodziny, przyjaciół & 8,1 \\
\hline Podróż poślubna & 6,9 \\
\hline Konferencje, konwenty & 2,7 \\
\hline Impuls & 1,6 \\
\hline Ślub & 1,4 \\
\hline Wydarzenia sportowe & 1,3 \\
\hline Spotkania firmowe & 0,9 \\
\hline Inne & 2,9 \\
\hline
\end{tabular}

Źródło: opracowanie własne na podstawie Annual Visitor Research Report Hawai’i Tourism Authority (2015)

\section{PodSUMOWANIE}

W świetle przeprowadzonych analiz można jednoznacznie stwierdzić, iż Hawaje są bardzo atrakcyjnym turystycznie regionem pod względem walorów i atrakcji związanych z bogatą historią i unikalną przyrodą, które niewątpliwie są ogromnym magnesem przyciągającym turystów z całego świata. Rokrocznie wzrasta liczba turystów odwiedzających Hawaje, za każdym razem ustanawiając nowy rekord, a co za tym idzie, także wzrasta przychód z turystyki. Jak już wcześniej wspomniano, gdy Hawaje stawały się nowym stanem USA, liczba turystów nie przekraczała ćwierci miliona rocznie, by 30 lat później wzrosnąć 25-krotnie.

Przeprowadzona analiza wykazała w kolejnych latach dalszy wzrost ruchu turystycznego, który w 2006 i 2007 roku osiągnął ponad 7,6 mln turystów. W 2008 roku sytuacja uległa gwałtownemu pogorszeniu, gdy rozwój turystyki na Hawajach gwałtownie spadł w wyniku zaprzestania działalności dwóch głównych linii lotniczych i statków wycieczkowych w stanie Aloha, przez co zmniejszyła się liczba turystów, a wysokie ceny paliw w lecie powstrzymały podróże. Duży wpływ na to pogorszenie miała również recesja w Japonii i USA, a także ekonomiczny krach w Kalifornii, który spowolnił przepływ turystów.

Od 11 lat do 2007 roku Japońscy turyści wydawali przeciętnie więcej pieniędzy niż amerykańscy, dlatego z tego powodu na Hawajach szczególnie ich ceniono. Wraz z upadkiem wartości jena i spowolnieniem japońskiej gospodarki przeciętny Japończyk pozostaje na Hawajach najczęściej tylko pięć dni. Przeciętny Azjata z Chin i Korei pozostaje na wyspach dłużej niż 9,5 dnia i wydaje o 25\% więcej niż dotychczas. Hawaje odnotowały wzrost liczby odwiedzających z Korei Południowej i Chin. W 2011 roku zwiększyła się też liczba przybywających turystów zagranicznych z Kanady i Australii odpowiednio o 13 i 24\%. W 2015 roku na Hawaje przybyło rekordowe ponad 8,5 mln odwiedzających (ponad 67\% z USA, 18,3\% z Japonii, 6,3\% z Kanady, 15,2\% z innych krajów), którzy wydali ponad 15 mld dol. 
Rozwój infrastruktury oraz zagospodarowanie turystyczne z licznymi hotelami, restauracjami i coraz lepszymi połączeniami komunikacyjnymi, szczególnie lotniczymi, sprawiły, że Hawaje stają się coraz popularniejszą destynacją dla turystów nie tylko z USA, ale i z całego świata, w tym także Europejczyków. Według Urzędu Turystyki na Hawaje w 2016 roku przybyło ok. 20,9 mln turystów, co oznacza wzrost o ok. 3\% w stosunku do 2015 roku. Wzrost ten był spowodowany zwiększeniem odwiedzin, głównie z USA i Korei Południowej.

Przeciętnie w ciągu dnia na wyspach przebywało ok. 220 tys. osób, dlatego należy zachować równowagę, by nie wywoływało to negatywnych konsekwencji w środowisku przyrodniczym i społecznym. Zwiększająca się liczba turystów powoduje z jednej strony rozwój i podnoszenie poziomu oferowanych usług, wpływając na ogólny rozwój stanu, z drugiej strony zaś wywiera negatywny wpływ na kulturę hawajską. Wśród lokalnej społeczności pojawiają się coraz większe obawy dotyczące wpływu turystyki na infrastrukturę i miejsca docelowe na Hawajach, dlatego należy rozwijać i promować turystykę zrównoważoną, opartą na zachowaniu hawajskiej kultury i ochronie zasobów naturalnych.

\section{Literatura}

References

Annual Visitor Research Report Hawai'i Tourism Authority (2003, 2005-2015). State of Hawai'i. Honolulu: Department of Business, Economic Development \& Tourism.

Ariyoshi, R. (2010). Hawaje - przewodnik. Białystok: National Geographic.

Chegaray, J. (1960). Hawaje. Warszawa: Wydawnictwo Iskry.

Compendium of Tourism Statistics (2003). Madrid: World Tourism Organization.

Cook, S., Word, G., Perry, T. (2005). Przewodnik Pascala - USA (część zachodnia). Bielsko-Biała: Pascal, 832-868.

Crocombe, R. (2001). The South Pacific. Suva: University of the South Pacific.

Długosz, Z. (2014). Geografia walorów turystycznych w zarysie - kraje pozaeuropejskie. Kraków: Wydawnictwo Attyka, 149.

Gay, J.-Ch. (1999). Le tourisme dans les Outre-Mers de l'Océan Pacifique. Mappemonde, 54(2), 26-29.

Gill, L.E. (2016, 3 września). Hawaii sees record 8.6 m visitors in 2015. Pacific Business News. Pozyskano z https://www.bizjournals.com/pacific/news/2016/01/28/hawaii-sees-record-8-6m-visitors-in-2015.html

Huetz de Lemps, Ch. (1989). Un exemple de macrocéphalie touristique: les îles Hawaii. W: Iles et tourisme en milieux tropical et subtropical. Talence: CEGET-CRET, 195-222.

Jackowski, A., Warszyńska, J. (1979). Podstawy geografii turyzmu. Warszawa: Wydawnictwo Naukowe PWN.

Kowalczyk, A. (2000). Geografia turyzmu. Warszawa: Wydawnictwo Naukowe PWN.

Kubota, L. (2010, 23 lutego). Surge in tourism from South Korea. Hawaii News Now. Pozyskano z http://www.hawaiinewsnow.com/Global/story.asp?S=13560702

Linda, W., Cuddihy, Ch., Stone, P. (1990). Alteration of Native Hawaiian Vegetation. Honolulu: University of Hawaii, Cooperative National Park Resources Studies Unit.

Makowski, J. (2008). Geografia regionalna świata. Warszawa: Wydawnictwo Naukowe PWN.

Merkel-Masse, M., Wichrowska, W. (2010). Szlaki marzeń - najpiękniejsze trasy podróżnicze świata. Ożarów Mazowiecki: Wydawnictwo Olesiejuk, 182-185.

Pearce, P., Stringer, P.F. (1991). Psychology and tourism. Annales of Tourism Research, 18(1).

Skoczek, P. (2005). Encyklopedia geograficzno-turystyczna. Bochnia: Wydawnictwo SMS.

Swenson, I. (2008). Geografia turystyczna świata, cz. 2. Warszawa: Wydawnictwo Naukowe PWN, 297.

Visitor Plant Inventory Report. Hawai'i Tourism Authority Tourism Research (2016). 
Wiles, G. (2012, 23 lutego). Hawaii's Fast-Growing Source for Tourists. Hawaii Business. Pozyskano z http://www.hawaiibusiness.com/Hawaii-Business/October-2010/Hawaii-rsquosFast-Growing-Source-for-Tourists /

Wojnowski, J. (2002). Wielka encyklopedia PWN. Warszawa: Wydawnictwo Naukowe PWN, 175, 452.

Woo, S. (2009, 17 sierpnia). Heavy Reliance on Tourism Has Hawaii's Economy Hurting. Wall Street Journal - Eastern Edition. A3. Academic Search Premier. EBSCO.

Yonan, Jr. (2010, 23 lutego). S. Korea tourists on rise. Honolulu Advertiser. Pozyskano z http:// the.honoluluadvertiser.com/article/2010/Mar/17/bz/hawaii3170326.html

Bożena Elżbieta Wójtowicz, dr hab. prof. UP, geograf, dydaktyk geografii, podróżnik. Zwiedziła większość krajów europejskich oraz Kubę, Mauritius, Meksyk, Indie, Nepal, Egipt, Maroko, Jordanię, Dominikanę. Kierownik Zakładu Dydaktyki Geografii Instytutu Geografii Uniwersytetu Pedagogicznego w Krakowie. Opublikowała ponad 210 prac naukowych w kraju i za granicą. Autorka monografii naukowej Geografia - rozwój zrównoważony, edukacja ekologiczna oraz współautorka i redaktor prac o charakterze monograficznym, m.in. Przyroda województwa świętokrzyskiego, Funkcje turystyki i krajoznawstwa w strategii rozwojów regionów w Polsce, Turystyka i ekologia - rozbudzanie potrzeb poznawczych i świadomości społeczeństwa, Kształcenie i dokształcanie nauczycieli geografii w Polsce i w krajach Unii Europejskiej, Edukacyjne zajęcia terenowe w Świętokrzyskim Parku Narodowym. Współautorka podręczników szkolnych: Geografia. Krajobrazy Polski do klasy czwartej, Geografia Ziemia - nasza planeta do klasy szóstej, Przyroda do klasy czwartej i piątej. Specjalistka z zakresu geografii, dydaktyki geografii, ochrony środowiska oraz turystyki i rekreacji.

Bożena Elżbieta Wójtowicz, Ph.D., is an assistant professor, geographer, geography teacher, traveller, who has visited most of the European countries, Cuba, Mexico, India, Nepal, Egypt, Morocco, Jordan, Dominican Republic. She is the Head of the Department of Didactics of Geography, Institute of Geography, the Pedagogical University of Cracow. She has published over 210 academic papers in the country and abroad. She is the author of the monograph "Geography Sustainable Development Environmental Education" and a co-author and editor of monographic works, such as Nature of the Świętokrzyskie Voivodeship; Functions of tourism and sightseeing in the strategy of regional development in Poland; Tourism and ecology - fostering the cognitive needs and public awareness; Education and additional training of teachers of geography in Poland and in the European Union; Educational fieldwork in Świętokrzyski National Park. She is also a co-author of textbooks: Geography. Polish Landscapes 4th grade; Geography. Earth - our planet 6th grade; Natural Science 4th and 5th grade. She is a specialist in the field of geography, teaching geography, the protection of environment, and tourism and recreation.

\section{Adres/address:}

Uniwersytet Pedagogiczny w Krakowie
Instytut Geografii
Zakład Dydaktyki Geografii
ul. Podchorążych 2, 30-084 Kraków, Polska
e-mail: bozena.wojtowicz@up.krakow.pl 